\section{Health legislation and democratic rule of law in Brazil}

\author{
Produção de normas jurídicas sobre saúde no \\ âmbito do estado democrático de direito brasileiro
}

\author{
Producción de normas legales sobre la salud en el \\ estado democrático brasileño
}

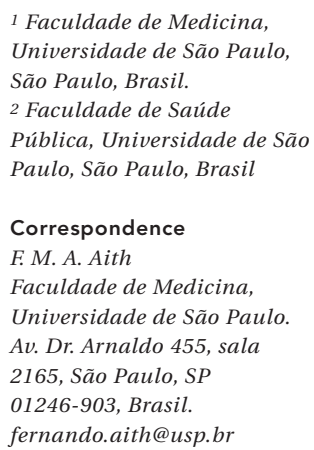

\section{Introduction}

Health legislation in Brazil is produced according to the country's prevailing democratic rule of law and is mainly passed by Congress and regulated by the Federal Executive Branch. Direct popular participation is indispensable and serves to temper the exercise of power by the above-mentioned branches. Legislation enacted through this process organizes the Brazilian health system and conditions individual, collective, government, and commercial behavior and activities with the purpose of ensuring the right to health.

The need for division of powers as a condition for balanced exercise of power in a society dates at least to 350 B.C., as discussed by Aristotle in Politics ${ }^{1}$. The idea was consolidated with the advent of modern states 2 and especially in the explicit legal separation of powers under their respective Constitutions (e.g., US Constitution. http://1776.org/us-constitution/, accessed on 20/ Aug/2014). The division of government power into three branches consolidates the system of checks and balances, the principal objective of which is to balance the exercise of power, since each branch oversees and places limits on action by the other two, thereby avoiding abuses and arbitrary interventions.

The complexity of social life, generating tension between the different branches of govern-
Fernando Mussa Abujamra Aith 1 Sueli Gandolfi Dallari 1,2

ment, led to a qualitative change in the concept of rule of law, incorporating the adjective "democratic". This signaled the need to balance traditional representative democracy (at the origin of the theory of separation of powers) with participatory democracy, a fundamental element for reinforcing the pursuit of justice in contemporary society. The field of health legislation is thus subject to constant tension between the powers and must be monitored closely by society in order to safeguard both the public interest and public health.

\section{RDC 52/2011 of the National Health Surveillance Agency (ANVISA)}

A case in point is ruling $R D C 52 / 2011$ by the Brazilian National Health Surveillance Agency (ANVISA), of October 6, 2011, which " provides for a ban on the use of amfepramone, fenproporex, mazindol, and their salts and isomers, as well as intermediate products and control measures for the prescription and dispensing of medicines that contain the substance sibutramine and its salts and isomers, as well as intermediate products, and establishes other provisions" 3 and the subsequent discussion on the ruling in the Brazilian Congress. 
$R D C 52 / 2011$ has been the object of both technical and legal controversy. Since 2006, ANVISA has conducted an in-depth discussion on regulation of the manufacturing and marketing of appetite suppressants. The matter has been: (i) submitted to public consultation in late 2006 4; (ii) discussed in $R D C 58 / 2007$, which rules on improvement in the control and inspection of psychoactive appetite suppressant substances; and (iii) the object of an in-depth technical study by the agency's technical staff, condensed in the Integrated Report on the Efficacy and Safety of Appetite Suppressants ${ }^{5}$, published in 2011.

According to ANVISA, as provided in $R D C$ $52 / 2011$, consumption of these substances by humans poses a health risk that calls for more rigorous regulation, by means of: (i) a ban on the manufacturing and marketing of the appetite suppressant drugs amfepramone, fenproporex, and mazindol and (ii) strict control of prescribing and dispensing sibutramine.

The ANVISA ruling has sparked intense debate in Brazilian society, to the point that the National Congress launched a bill of law with the sole purpose of overruling RDC 52/2011. Initially submitted to the Chamber of Deputies by Congressman Beto Albuquerque, Bill of Law $1,123 / 2013^{6}$ contends that "the ban on the manufacturing and marketing of the appetite suppressants amfepramone, fenproporex, and mazindol and the highly restricted permission for the use of sibutramine caused great dissatisfaction among the medical community and constitute a step backwards in the treatment of obesity in Brazil."

Passed by the Chamber of Deputies, the bill is now under final review in the National Senate with the name PDS 52/2014. The bill has been approved by the Senate Committee on Constitution, Justice, and Citizenship, based on Report 620/2014 submitted by rapporteur Senator Lúcia Vânia, who states that "RDC 52/2011 clashes with Article 5 (paragraph XIII) of the National Constitution by interfering with the free exercise of the medical profession. In addition, the ban on medicines for treatment of obesity prevents access to health by a significant portion of the population, thereby violating Article 196 of the Constitution" 7.

However, it should be noted (to illustrate the tension mentioned above) that the free exercise of any profession does not preclude government regulatory power by both the Legislative and Executive Branches. If the bill passes, it will prevent the enforcement of $R D C 52 / 2011$, casting aside the mechanisms of direct democracy that influenced the ANVISA ruling.

\section{Constitutional limits on regulatory power by the Executive Branch}

The basis for limiting the regulatory power of the Executive Branch lies in the principle of legality. This principle had its origins in the English Magna Carta of 1215 and was consolidated by the French Revolution in 1789, but acquired a quite different meaning over the centuries. As the pillar of modern positive law, the principle of legality promoted laws to the position of primary sources in the legal system. The prime functions of the law include the guarantee of legal security for citizens; the limitation of powers exercised by rulers, who may only do what is authorized by law; and the guarantee of democracy, according to which the law expresses the people's will, or the social contract.

The complexity of modern legal systems led to a proliferation of legal provisions resulting from regulation, that is, rulings issued outside the Legislative Branch by specific administrative authorities wielding normative power. Examples in Brazil include executive orders issued by the President of the Republic (Article 84, IV), State Governors, and Mayors, rulings by cabinet ministers, Federal, State, and Municipal secretaries and presidents of agencies, and resolutions by the collegiate boards and councils of regulatory bodies.

According to traditional rule-of-law theory, the normative power of the Executive Branch is specifically constrained by checks on executive rulings. At the beginning of this new millennium, democratic rule of law requires more than traditional checks and balances. The principle of legality, which has never been void of political content, is rooted in the logic by which all power comes from the people and is exercised by the people, both indirectly (electing representatives) and directly (see Federal Constitution of Brazil, 1988, article 1 , sole paragraph).

\section{Production of legal provisions and health democracy}

The democratic production of health legislation is written into the Constitution, which recognizes the people's sovereignty (Federal Constitution of Brazil, 1988, article 1, sole paragraph) and the Constitutional provision of Article 198, III. The assumption is that the more democratic the elaboration of a legal provision, the greater its social legitimacy, efficacy, and effectiveness. This is true for both the laws passed by the Legislative Branch and the rules issued by the Executive. The expansion of mechanisms for society's participation 
in the lawmaking process is the main path for building a true health democracy in Brazil. The legal definition of health, the effective scope of this right, and the extent of the state's duty are expressed by the state's normative choices vis-à-vis enforcement of the right to health. Such choices must be made in an environment of health democracy which allows society's participation in the decision-making process and universal and egalitarian access to the services provided by the public health system.

The case of $R D C 52 / 2011$ illustrates the traditional checks exercised by the Legislative Branch. However, Brazil should go beyond these traditional checks and balances between the powers and expand society's participation in the elaboration of legal provisions in health. It is thus nec-

\section{Contributors}

F. M. A. Aith and S. G. Dallari participated in the overall conceptualization, research, and final writing of the article. essary to value the democratic experience in the elaboration of $R D C 52 / 2011$ and to ensure that the formal mechanism of separation of powers does not overlook the use of public hearings (direct democracy) and technical reports by specialized agencies (representative democracy).

Tension between the Executive and the Legislative in health is inherent to the prevailing legal system. In order for the tension between the Executive and the Legislative in the lawmaking process to become a social pact and to protect the right to health, health democracy must be deepened. The foundations for health democracy require recognition of health as a fundamental human right and the creation of mechanisms for society's participation in the state's decisionmaking process, including legal decisions.
1. Aristóteles. Política. Brasília: Editora da UnB; 1999.

2. Montesquieu. O espírito das leis. São Paulo: Editora Martins Fontes; 2000.

3. Agência Nacional de Vigilância Sanitária. Resolução de Diretoria Colegiada - RDC no 52, de 06 de outubro de 2011. Dispõe sobre a proibição do uso das substâncias anfepramona, femproporex e mazindol, seus sais e isômeros, bem como intermediários e medidas de controle da prescrição e dispensação de medicamentos que contenham a substância sibutramina, seus sais e isômeros, bem como intermediários e dá outras providências. Diário Oficial da União 2011; 10 out.

4. Agência Nacional de Vigilância Sanitária. Consulta Pública no 89, de 12 de dezembro de 2006. Diário Oficial da União 2006; 13 dez.

5. Agência Nacional de Vigilância Sanitária. Relatório integrado sobre a eficácia e segurança dos inibidores de apetite. http://www.anvisa.gov.br/hotsite/ anorexigenos/pdf/Relat\%F3rio\%20Integrado\%20 Inibidores\%20do\%20Apetite\%202011_final.pdf (accessed on 20/Aug/2014).
6. Albuquerque B. Projeto de Decreto Legislativo no 1.123/2013. Susta a Resolução - RDC no 52/2011, de 6 de outubro de 2011, da Agência Nacional de Vigilância Sanitária (ANVISA), que "Dispõe sobre a proibição do uso das substâncias anfepramona, femproporex e mazindol, seus sais e isômeros, bem como intermediários e medidas de controle da prescrição e dispensação de medicamentos que contenham a substância sibutramina, seus sais e isômeros, bem como intermediários e dá outras providências". http://www.camara.gov.br/propo sicoesWeb / prop_mostrarintegra;jsessionid=9F47 06478BF4D98AE30E5AFA94A10091.proposicoesW eb2? codteor $=1115399 \&$ filename $=$ PDC $+1123 / 2013$ (accessed on 20/Aug/2014).

7. Vânia L. Parecer no 620 de 2014. http://www.sena do.gov.br/atividade/Materia/getPDF.asp?t=153450 \&tp=1 (accessed on 20/Aug/2014).

Submitted on 26/Aug/2014

Approved on 01/Sep/2014 